\title{
Food Allergy Prevention and Treatment by Targeted Nutrition
}

\author{
Ralf G. Heine \\ Paediatric Care, Nestlé Health Science, Vevey, Switzerland
}

\section{Key Messages}

- In view of the dramatic rise in the prevalence of food allergy globally, effective prevention strategies have become a public health priority.

- The early introduction of complementary diet and food allergens from 4 months of age is currently one of the most promising approaches in the prevention of food allergies.

- While the strict food allergen avoidance remains the main treatment strategy for food allergies, immunotherapy via the oral or epicutaneous route have emerged as effective and feasible future treatment strategies.

\section{Keywords}

Allergy · Atopy · Breastfeeding · Infant formula ·

Microbiome $\cdot$ Prevention

\begin{abstract}
In view of the dramatic rise in the prevalence of food allergy globally, effective prevention strategies have become a public health priority. Several models have emerged around the etiology of food allergy, including the hygiene hypothesis, dual allergen exposure hypothesis, and vitamin D hypothesis. These form the basis for current and potential prevention strategies. Breastfeeding remains a key pillar of primary al-
\end{abstract}

lergy prevention. Other nutritional interventions, including the use of whey-based, partially hydrolyzed formula in nonbreastfed infants, also play an important role. In recent years, there has been a shift away from prolonged food allergen avoidance to the proactive allergen introduction from 4 months of age. This approach is supported by 2 pivotal randomized clinical trials showing that the early introduction of peanut and other food allergens significantly reduces the risk of food allergy. However, the implementation of this strategy at the population level still raises significant logistic problems, including patient selection and development of suitable food formats for young infants. Other prevention strategies, including vitamin D supplementation, are currently under evaluation. Maternal elimination diets during pregnancy and lactation are not recommended for allergy prevention. The treatment of food allergies has also seen major transformations. While strict allergen avoidance is still the key treatment principle, there is a greater focus on desensitization and tolerance induction by oral and epicutaneous immunotherapy. In addition, specialized hypoallergenic infant formulas for the treatment of infants with cow's milk allergy have undergone reformulation, including the addition of lactose and probiotics in order to modulate the gut microbiome and early immune responses. Further research is needed to inform the most effective food allergy prevention strategies at the population level. In addition, the wider application of food allergen immunotherapy may provide better health outcomes and improved quality of life for families affected by food allergies.

(c) 2018 S. Karger AG, Basel

\section{KARGER}

(c) 2018 S. Karger AG, Basel

E-Mail karger@karger.com

www.karger.com/anm
Ralf G. Heine, MD, FRACP

Paediatric Care

Nestlé Health Science

55 Avenue Nestlé, $\mathrm{CH}-1800$ Vevey (Switzerland)

E-Mail ralf.heine@nestle.com 


\section{Introduction}

Over the past 2 decades, the prevalence of allergic disorders has increased dramatically [1-3]. The greatest increase has been observed in infants and children with food allergies or atopic eczema [4, 5]. In Europe and Northern America, food allergy is estimated to occur in $1-5 \%$ of the population [1]. In Australia, a populationbased study found a prevalence of challenge-proven food allergy of over $10 \%$ which is the highest rate globally [6]. Overall, prevalence figures for food allergy and anaphylaxis appear to be steadily rising [7]. Effective allergy prevention has therefore become a global public health priority [8].

Nutritional interventions play a central role in the prevention and treatment of food allergies (Table 1). In recent years, clinical approaches have undergone significant changes [3]. In the food allergy prevention space, greater focus has been placed on the early introduction of the complementary diet in infancy [9] (Fig. 1). This is in contrast to the previous approach of prolonged food allergen avoidance which, in hindsight, may have paradoxically increased the rate of food allergies [10-12]. In the area of food allergy treatment, there have also been major advances, including a shift from mere food allergen avoidance to proactive food allergen immunotherapy [13]. In addition, there is renewed interest in the role of gut microbiome-modifying therapies in an attempt to promote immunological tolerance development via the gut-associated immune system [14-16]. This review summarizes the previous and current approaches to dietary food allergy prevention and treatment and highlights areas of uncertainty or controversy, as well as priorities for future research.

\section{Breastfeeding}

Breastfeeding is one of the main pillars in both food allergy prevention and treatment [17-21]. Breast milk provides the most appropriate source of nutrition for the young infant as it contains a specific nutrient mixture, growth factors, and protective maternal antibodies. The World Health Organization (WHO) guidelines on complementary feeding of 2001 recommend exclusive breastfeeding for at least 6 months. However, this recommendation has been challenged in countries with a high prevalence of food allergies, as the early dietary introduction of allergens appears to protect from food allergies [22, 23]. Recent guidelines on the prevention of food allergies from Europe, the USA, and Australia have recommended the introduction of solids from 4-6 months of age [2428 .
Table 1. Nutritional strategies for the prevention of food allergy

\section{General}

- Exclusive breastfeeding for 4-6 months

- Use of whey-based, partially hydrolyzed formula (if exclusive breastfeeding is not possible)

Introduction of complementary diet from 4 months

- Early introduction of food allergens (peanut, egg, and others) in infants at high risk of developing food allergies

Microbiome-modifying interventions

- Probiotics (e.g., Lactobacillus rhamnosus GG)

- Prebiotics (e.g., fructo-oligosaccharides,

galacto-oligosaccharides)

- Human milk oligosaccharides (e.g. 2'-fucosyllactose and lacto-N-neotetraose)

Immune-modulating nutrients

- Maternal omega-3 polyunsaturated fatty acid supplementation (docosahexaenoic acid, eicosapentaenoic acid)

- Vitamin D (under investigation)

Breastfeeding is associated with the establishment of fecal microbiota high in Bifidobacteria [29]. Human milk oligosaccharides (HMO) promote the colonization of the gut with Bifidobacteria which is thought to promote mucosal tolerance via interaction with regulatory T-lymphocytes and Toll-like receptors [30]. Breastfeeding itself does not appear to confer a strong protective effect against food allergies [21]. However, the duration of exclusive breastfeeding appears to influence the risk of allergic disease $[31,32]$. The protective effect of breastfeeding on eczema in the first 2 years of life appears to be modified by maternal allergy status [33]. Exclusively breastfed infants can express clinical manifestations of food allergy, including food protein-induced proctocolitis and multiple food intolerance of infancy [34-37]. These often respond to treatment with hypoallergenic maternal elimination diets which eliminate cow's milk or other food allergens $[38,39]$. In some infants who failed a trial of maternal dietary elimination, treatment with a hypoallergenic formula may be required [40-42]. Maternal elimination diets during pregnancy and lactation for the purpose of allergy prevention are not recommended $[18,43]$.

\section{Prevention}

Primary food allergy prevention aims to reduce the infant's risk of sensitization to food allergens [44]. By contrast, secondary prevention aims to prevent the clinical expression of allergic disease in individuals who are either 
Fig. 1. Integrated model of nutritional interventions and skin care for food allergy prevention.

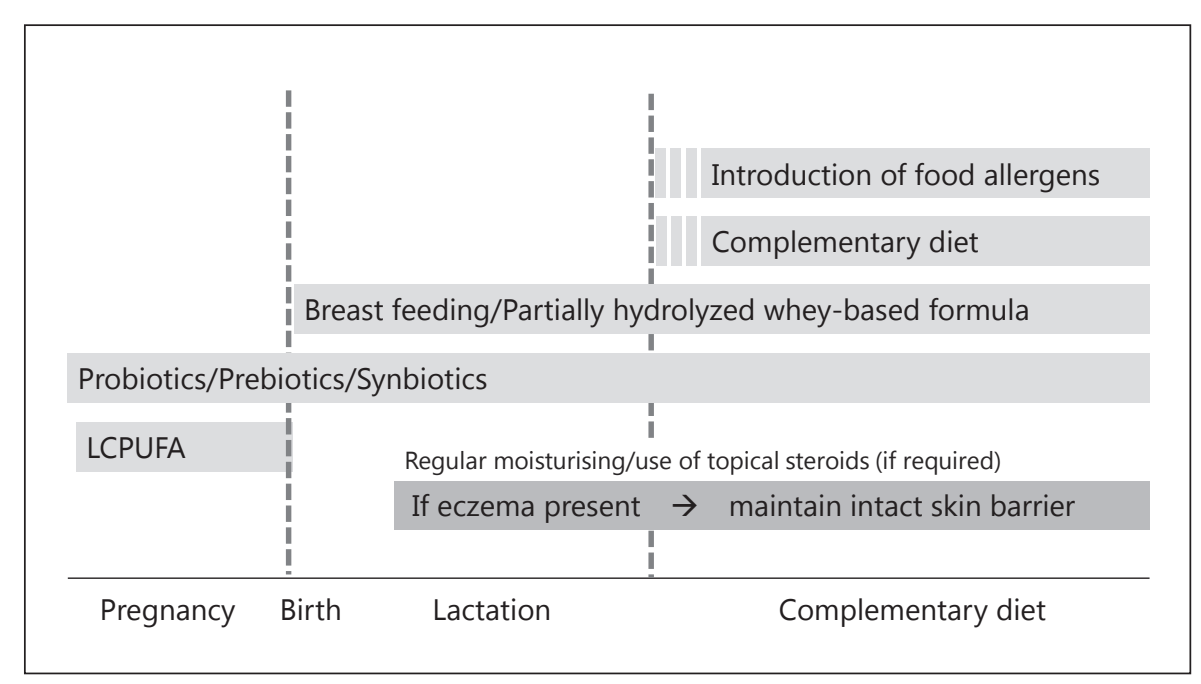

allergen sensitized or who already manifest other allergic disorders, such as atopic dermatitis or asthma. The prevention of food allergies and atopic dermatitis by nutritional interventions has been explored for the past 2 decades with a broad range of approaches. In addition to the promotion of breastfeeding, these have included the use of partially hydrolyzed formula (PHF) and a range of maternal elimination diets $[43,45]$. Supplementation with probiotics, prebiotics, and specific nutrients has also been explored [46, 47]. Some of these interventions have been trialed in high-risk populations, either in families with a history of allergies, or in infants who are showing evidence of food sensitization or eczema. Other studies have assessed the preventive effect of interventions at the population level without selecting for allergic history. This distinction is important when the findings of prevention trials are translated into population-based health policies $[22,48]$.

Prevention strategies have been developed around 3 main hypotheses on the etiology of food allergies: the hygiene hypothesis, the dual allergen exposure hypothesis, and the vitamin D hypothesis $[11,49,50]$. The following sections will summarize current preventive strategies in the context of these hypotheses.

\section{Hygiene Hypothesis}

Gut microbiota and environmental microbial burden play a central role in early immune development and are likely to influence immunological events that lead to allergy $[49,51,52]$. The hygiene hypothesis assumes that there is an immune deviation to T-helper 2 reactions due to reduced early microbial exposure and a lack of fecal microbial diversity $[53,54]$. For example, growing up in a rural farm environment has been shown to significantly reduce the risk of asthma and allergic disease in children $[49,55]$. There are significant differences in the gut microbiota profiles between allergic and nonallergic infants and children $[56,57]$. Infants with IgE-associated eczema have significantly reduced fecal microbial diversity in the first month of life, compared to nonatopic infants $[54,58]$. Modification of early gut colonization and fecal microbial diversity in infancy may thus provide an avenue for preventive or therapeutic strategies [59]. Probiotic or prebiotic supplementation has been shown to modify the risk of allergies, particularly for atopic dermatitis in infancy [60-62]. The World Allergy Organization Guidelines recommend the use of probiotics and prebiotics for the prevention of eczema and allergies, but caution that the available evidence is of very low certainty $[63,64]$.

\section{Probiotics}

Infants with allergies have been shown to have significantly lower numbers of fecal Bifidobacteria, compared to healthy infants [65]. Allergy prevention via supplementation with probiotic bacteria therefore appears to be a promising approach. The effects of probiotics are mainly mediated via the innate immune system (Toll-like receptors), resulting in the promotion of T-helper 1 differentiation, production of regulatory cytokines (IL-10 and TGF-beta) and enhanced intestinal IgA responses [66]. Several studies have demonstrated that perinatal administration of probiotics to mothers in the last weeks of pregnancy and to infants in the first few months of life was associated with a significant reduction in atopic ec- 
zema [67-69]. Nevertheless, results have been varied, depending on the probiotic strain, dose, timing and food matrix used. A study using Lactobacillus acidophilus (LAVRI A1) even showed a paradoxical increase in allergic sensitization [70]. These studies highlight that clinical outcomes depend on the specific probiotic strains used. The role of probiotics in allergy prevention requires further study [46].

\section{Prebiotics}

HMO are complex, nondigestible oligosaccharides with prebiotic properties in breast milk which provide a specialized substrate for Bifidobacteria. In the past, infant formulas were devoid of prebiotic oligosaccharides [71]. Over the past decade, several manufactured prebiotics have been added to infant formula, including plant-based long-chain fructo-oligosaccharides (FOS) and shortchain galacto-oligosaccharides (GOS). GOS and FOS have been shown to increase counts of fecal Bifidobacteria in formula-fed infants $[72,73]$. A randomized study examined the effects of a FOS/GOS-supplemented hydrolyzed formula on atopic eczema in formula-fed infants during the first 6 months of life [74]. In that study, the FOS/GOS group had significantly lower rates of eczema compared to the placebo group, although eczema severity was similar for both treatment arms. A more recent European multi-center randomized controlled trial assessed the effect of prebiotics in healthy, low-risk infants from 8 weeks to 12 months [75]. Prebiotics reduced the incidence of atopic dermatitis by $44 \%$ at 12 months. Again, disease severity was not affected. Further studies are needed to assess the role of GOS and FOS in allergy prevention [62].

HMO in breast milk provide the substrate for specific microbes and significantly influence early microbial gut colonization [76, 77]. Recently, 2 manufactured HMO ( $2^{\prime}$-fucosyllactose and lacto- $\mathrm{N}$-neotetraose) have been added to standard cow's milk-based formula [78]. In preclinical studies, HMO have been shown to attenuate allergic responses in cow's milk-sensitized mice [79]. The role of HMO in the prevention and treatment of food allergies is at this stage not clearly defined but represents a promising area for future research $[80,81]$.

\section{Dual Allergen Exposure Hypothesis}

The dual allergen exposure hypothesis (via skin and gut) is based on the observation that infants with eczema have a high risk of developing IgE-mediated food allergies [11]. While allergen contact via eczematous skin may cause allergic sensitization, the exposure via the gastrointestinal tract is more likely to induce immunological tolerance $[11,82,83]$. Prolonged avoidance of a food allergen in infants with eczema may paradoxically increase the risk of food allergies $[12,84]$. Previously, the delayed introduction of common food allergens (cow's milk after 12 months, egg after 2 years, and peanut after 3 years) was recommended in an attempt to prevent food allergy [10]. Findings from several small studies provided support for the concept of a "window period" for tolerance induction, whereby tolerance is more likely to be achieved if weaning solids are introduced between 4 and 6 months of age. This reflects feeding practices in many European countries, but is not supported by the WHO guidelines on complementary feeding.

The Australian HealthNuts Study showed that the risk of developing egg allergy increased significantly if egg was introduced after 12 months of age [85]. This finding prompted to question the recommendation of delaying the introduction of egg beyond 12 months of age. The LEAP (Learning Early about Peanut) study was the pivotal study demonstrating that the early introduction of peanut into the infants diet from 4 months conferred a protective effect against peanut allergy in high-risk infants [86]. This study was based on the observation that infants in Israel who were exposed to peanut in a teething snack had a low risk of peanut allergy, while Jewish infants in the United Kingdom who introduced peanut generally after 12 months of age had a high risk. The subsequent clinical study enrolled infants with pre-existing egg allergy or eczema and randomized them to introduce peanut from 4 months, or to continue strict peanut avoidance. The study showed overwhelming evidence of a protective effect against peanut allergy (70$86 \%$ relative incidence reduction) in those who introduced peanut early between 4 and 11 months of age. A supplementary analysis found that the skin prick test wheal diameter at the time of peanut introduction predicted the tolerance development in those who avoided peanut, with the greatest benefit seen between 6 and 11 months [87]. This analysis provided additional insights on the best timing of the dietary introduction of food allergens in high-risk infants.

A second study, the Enquiring about Tolerance (EAT) study, prospectively examined if the early introduction of
36

Ann Nutr Metab 2018;72(suppl 3):33-45 DOI: $10.1159 / 000487380$
Heine 
6 food allergens (from 4 months of age) while breastfeeding could reduce the risk of food allergy in a nonallergic population [88]. On per-protocol analysis, there was a significant protective effect against food allergy. However, the study overall failed on intention-to-treat analysis due to a large proportion of participants who were unable to adhere to the study regimen. This raised questions around the logistics of introducing foods early in infancy, including finding suitable food formats that would allow the delivery of food proteins in adequate doses to breastfed infants $[22,27]$.

\section{Partially Hydrolyzed Formula}

The role of hydrolyzed formula in allergy prevention has been studied for more than 2 decades. Several studies have explored the tolerogenic potential of cow's milk peptides in hydrolyzed formula. The German Infant Nutritional Intervention (GINI) study is to date the largest, quasi-randomized trial examining the role of hydrolyzed formula in the prevention of allergies [89]. Infants with a family history of allergies were randomized to receive cow's milk-based formula, whey-based PHF, whey-based extensively hydrolyzed formula (EHF), or casein-based EHF at the time of weaning. That study found a sustained protective effect against atopic eczema for whey-based PHF and casein-based EHF [89]. Follow-up studies of the GINI cohort have demonstrated a sustained preventive effect of hydrolyzed formulas until 10 years of age, compared to cow's milk-based formula [90]. A Cochrane review on hydrolyzed formulas in allergy prevention found a limited beneficial effect, compared to cow's milk-based formula, in "high-risk" infants with a family history of atopy [91]. Two other metaanalyses also confirmed a preventive effect, mainly for atopic dermatitis $[92,93]$. Others have questioned the role of PHF and cautioned against overstating its preventive effects $[94,95]$. Boyle et al. [96] in their meta-analysis found no support for a preventive effect of PHF against allergic disease. However, pooling of data on hydrolyzed formulas in meta-analyses may be problematic due to significant heterogeneity of PHF products. A more recent meta-analysis addressed this issue and only included studies using 100\%-whey PHF [97]. That study found a preventive effect for all allergies and eczema, but acknowledged limitations in the certainty of available data. The current Allergy Prevention Guidelines by the European Academy of Allergy and Clinical Immunology
(EAACI) recommend the use of PHF with a documented preventive effect in infants at high-risk of allergy if breastfeeding is insufficient or not possible [98].

\section{Vitamin D Hypothesis}

Several studies have demonstrated an association between low vitamin D levels and food allergy $[99,100]$. An Australian study showed that vitamin D insufficiency (serum level $<50 \mathrm{nmol} / \mathrm{L}$ ) was associated with a significantly increased risk of egg and/or peanut allergy [101]. This finding concurred with the observation that the prevalence of food allergy and eczema follows a north-south gradient, being more common in regions with less sun exposure and lower skin-derived vitamin D levels [102]. Adequate vitamin $\mathrm{D}$ levels in the first year of life may therefore provide protection against the development of food allergies. By contrast, vitamin D may also have undesirable immune-modulating effects and, in high doses, increase the risk of allergic sensitization. Vitamin D has been shown to inhibit the maturation of dendritic cells and impede the development of T-helper 1 responses. In theory, vitamin D therefore could increase the risk of allergic disorders in infancy [103]. This is supported by a recent German birth cohort study (LINA study) which found that high vitamin $\mathrm{D}$ levels during pregnancy and at birth were associated with an increased risk of food allergy [104]. The varying effects of vitamin D on allergy risk have been explained by a U-shaped dose response curve, i.e., normal vitamin D levels may confer a protective effect while abnormally high or low levels may increase the allergy risk [100]. The aforementioned studies suggest that both vitamin $\mathrm{D}$ insufficiency and oversupplementation are risk factors for allergies [99]. The VITALITY trial, a prospective randomized trial, is currently underway to assess the role of postnatal vitamin $\mathrm{D}$ supplementation as a preventive strategy against IgE-mediated food allergy, eczema, and lower respiratory tract infections [105].

\section{Omega-3 Long-Chain Polyunsaturated Fatty Acids}

Maternal diets high in omega-3 long-chain polyunsaturated fatty acids (LCPUFA) are thought to have a protective effect against the development of allergies in the newborn [106]. Supplementation with docosahexaenoic acid and eicosapentaenoic acid during pregnancy has been shown to increase LCPUFA concentrations in breast milk [107]. A large randomized clinical trial of maternal 
fish oil supplementation during pregnancy demonstrated a significant decrease in cord blood concentrations of Th- 2 cytokines (IL- 4 and IL-13) as well as increased levels of oral tolerance-inducing TGF-beta [108]. Palmer et al. [109] assessed the effect of high-dose fish oil supplementation in high-risk infants (with a positive family history of atopy). Pregnant mothers were randomized to receive either $800 \mathrm{mg}$ docosahexaenoic acid plus $100 \mathrm{mg}$ eicosapentaenoic acid or vegetable oil from 21 weeks' gestation until delivery. Primary outcomes were infantile eczema and food sensitization at 12 months of age. Infants in the fish oil-supplemented group had significantly lower rates of atopic eczema and egg sensitization. In another study by the same group [110], high-risk infants were randomized to $280 \mathrm{mg}$ docosahexaenoic acid plus $110 \mathrm{mg}$ eicosapentaenoic acid daily or olive oil (control) from birth to 6 months of age. In that study, between-group comparisons revealed no differences in allergic sensitization, eczema, asthma, or food allergy. In summary, fish oil supplementation during pregnancy reduced the risk of atopic eczema and food sensitization, whereas dietary supplementation after birth appeared to be ineffective.

\section{The treatment of food allergies relies on the strict elimination of the offending allergens}

\section{Treatment}

The treatment of food allergies relies on the strict elimination of the offending allergens. In exclusively breastfed infants who react to allergens via breast milk, maternal elimination diets have been shown to be effective $[34,38]$. The complementary diet also needs to be free of the food allergen. In formula-fed infants with cow's milk allergy (CMA), specialized hypoallergenic formulas are the treatment of choice. The main types of these treatment formulas are EHF and amino acid-based formula (AAF) [40, $111,112]$. Hypoallergenic elimination diets need to be carefully supervised for nutritional adequacy [38]. Despite attempts to strictly eliminate offending food allergens from the diet, accidental reactions are relatively common. The risk of inadvertent allergic reactions and anaphylaxis significantly impacts the quality of life of patients and families $[113,114]$. Precautionary allergen labelling is in many instances still confusing or incomplete $[115,116]$. Reassuringly, several countries have introduced legislation towards more consistent allergen labelling [117].

\section{Maternal Elimination Diets}

Food allergens that are secreted into breast milk may elicit allergic symptoms in the infant [118]. While maternal elimination diets have no role in primary food allergy prevention, they have become a widely used intervention in breastfed infants with food allergies [38]. Poorly supervised or broad-based maternal elimination diets are not without nutritional risks for both mother and infant [119]. The nutritional adequacy of the maternal diet should be assessed and monitored by a pediatric dietitian [120]. Calcium supplementation is generally recommended if cow's milk products are eliminated from the maternal diet.

\section{Extensively Hydrolyzed Formula}

Whey- or casein-based EHF are considered the firstline treatment of formula-fed infants with CMA [121]. These formulas contain small cow's milk peptides that are produced via enzymatic breakdown and ultrafiltration of intact cow's milk proteins. There are significant differences in the molecular weights and profiles of peptides in EHF. This may explain differences in the risk of allergic reactions to various EHF $[122,123]$. A task force of the European Academy of Allergy and Clinical Immunology (EAACI) has therefore called for stricter standards for the definition of EHF marketed in Europe, including preclinical testing, quality assurance, and labelling requirements [124].

Some recently developed EHF contain highly purified lactose. Contrary to common perception, lactose is tolerated well by most infants with CMA [125]. The only exception are infants with cow's milk protein-induced enteropathy and secondary lactase deficiency due to villous damage (Table 2). These infants may develop increased diarrhea after lactose ingestion. However, a lactose-containing EHF can generally be reintroduced once the diarrhea has settled and the small intestinal mucosal integrity has been restored. As young infants do not absorb all ingested lactose, it is considered a prebiotic compound with positive effects on the gut microbiome of infants [126]. Compared to lactose-free formula, lactose-containing formula is associated with increased counts of Bifidobacteria and increased concentrations of short-chain fatty acids. This may confer a protective effect on colonic mucosal integrity and have a beneficial effect on early immune development [53]. There is to date no data showing a direct effect on tolerance development or allergic risk.

EHF contains trace amount of allergenic peptides and therefore has a small residual allergenicity with the risk of allergic reactions [127]. Conversely, the antigenic content in EHF may have the potential to actively promote toler-
38

Ann Nutr Metab 2018;72(suppl 3):33-45 DOI: $10.1159 / 000487380$
Heine 
Table 2. Treatment of cow's milk allergy (CMA) in infants

\begin{tabular}{|c|c|c|c|c|}
\hline $\begin{array}{l}\text { IgE-mediated CMA } \\
\text { With anaphylaxis } \\
\text { Without anaphylaxis }\end{array}$ & $\begin{array}{l}\text { Only required if reacting to } \\
\text { cow's milk protein in breast milk }\end{array}$ & $\begin{array}{l}\text { AAF } \\
\text { EHF }\end{array}$ & $\mathrm{EHF}^{1}$ & $\begin{array}{l}\text { No } \\
\text { No }\end{array}$ \\
\hline $\begin{array}{l}\text { Cow's milk protein-induced } \\
\text { proctocolitis }\end{array}$ & $\begin{array}{l}\text { Only required if reacting to } \\
\text { cow's milk protein in breast milk }\end{array}$ & EHF & $\mathrm{AAF}$ & No \\
\hline
\end{tabular}

EHF, extensively hydrolyzed formula; AAF, amino acid-based formula, FPIES, food protein-induced enterocolitis syndrome.

${ }^{1}$ In infants with a history of anaphylaxis, EHF should be first trialed under medical supervision.

ance development [128]. This ability may be further enhanced by the addition of probiotic bacteria or other ingredients. Berni Canani et al. [129] conducted a randomized clinical trial of EHF supplemented with Lactobacillus rhamnosus GG (LGG) in infants with CMA. In that trial, infants receiving the probiotic-supplemented formula had a greater chance of achieving tolerance to cow's milk protein at 6 and 12 months of age. This effect appeared to be, at least in part, modulated by an expansion of butyrate-producing gut microbiota [130]. At the 3-year follow-up of another cohort, there appeared to be a greater rate of resolution of IgE-mediated CMA as well as a lower incidence of other allergic manifestations in response to LGG-supplemented EHF [15]. These studies highlight the potential for probiotic supplementation of EHF to hasten tolerance development as well as the importance of butyrate as a likely key mediator in tolerance acquisition. However, further clinical trials are required to confirm the tolerogenic effects of LGG and assess the potential benefits of other probiotic strains with regard to early immune development.

\section{Amino Acid-Based Formula}

AAF is a synthetic, nutritionally complete, cow's milk antigen-free formula containing free amino acids, which is used in the treatment of infants with severe CMA. AAF is therefore not a first-line treatment but recommended for infants who have failed treatment with EHF, as well as infants with cow's milk anaphylaxis [112], multiple food intolerance of infancy $[36,131]$, or eosinophilic esophagitis [132]. As tolerance development is thought to be an antigen-driven process [128], AAF is unlikely to promote tolerance development [128]. The addition of prebiotics or probiotics to AAF may have beneficial effects on gut microbiome, but clinical outcome data are not currently available [133].

\section{Other Potential Formula Options}

Should EHF or AAF not be available, other formula options may be considered. Soy formula is frequently used for economic reasons in countries with limited access to hypoallergenic formulas [134]. However, the role of soy formula in the treatment of infants with CMA remains controversial. Generally, soy formula is not recommended as a first-line treatment in infants with CMA under 6 months of age [112]. Hydrolyzed rice-based formula has become available in recent years as a hypoallergenic formula in infants with CMA $[135,136]$. The hydrolysis is required due to the poor solubility and hydrophobic properties of rice protein. These formulas are tolerated well and may have a taste advantage over casein- or whey-based EHF. The exact role of hydrolyzed rice-based formulas needs to be clarified. Importantly, rice-based infant formulas must not be confused with rice "milk" beverages which are low-protein, low-energy cereal milks which are not suitable for infant feeding due to the risk of severe protein-energy malnutrition [137]. Mammalian milks, including goat's or sheep's milk formula, are often 


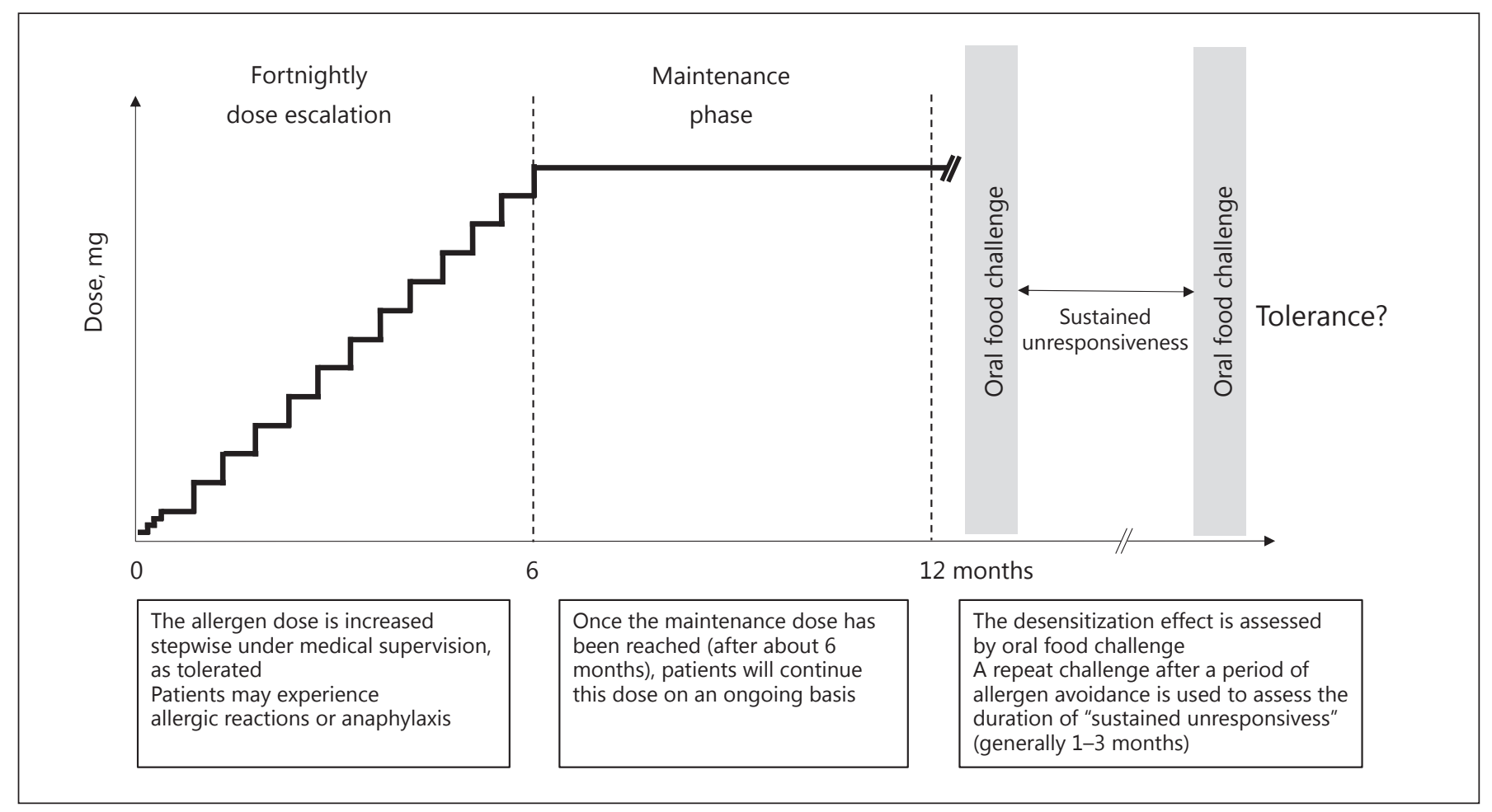

Fig. 2. Dosing schedule of oral peanut immunotherapy.

considered as alternatives to cow's milk formula but are not suitable due to a high rate of protein homology and allergic cross-reactivity [138]. Cross-contamination with cow's milk protein during production may also occur. Although often perceived as safe alternatives to cow's milk formula, these mammalian milk formulas may cause significant allergic reactions, including anaphylaxis [139].

\section{Food Allergen Immunotherapy}

The concept of food allergen immunotherapy is not new. The concept was first described by Schofield in 1908 in a 13-year-old boy with egg allergy who was successfully desensitized by introducing egg in incremental doses [140]. Since then, 3 main clinical immunotherapy concepts to food allergens have emerged: oral, sublingual, and epicutaneous immunotherapy. The focus has so far mainly been on children with the most prevalent food allergies to peanut, egg, and cow's milk.

Oral immunotherapy (OIT) involves the stepwise introduction of a food allergen via the oral route, starting with milligram doses [141] (Fig. 2). The administration of initial doses and stepwise updosing occurs under medical supervision, generally with fortnightly intervals, until a maintenance dose has been achieved after about 6 months [13]. For OIT to peanut, $79 \%$ of peanut-allergic patients were effectively desensitized to $443 \mathrm{mg}$ of peanut protein [141]. The remaining patients were unable to tolerate the treatment due to significant allergic side effects, ranging from persistent gastrointestinal symptoms to anaphylaxis. Combination therapy of OIT with anti-IgE (omalizumab) or other biologicals is being explored as an avenue to reduce the rate and severity of adverse events during updosing [142]. Importantly, patients generally do not achieve true, lasting immunological tolerance but a state of non-responsiveness, called "desensitization." The duration of "sustained unresponsiveness" to an allergen after cessation of OIT maintenance treatment varies, but the allergic phenotype generally recurs gradually over weeks to months [13].

Epicutaneous immunotherapy (EPIT) is based on the delivery of food allergens via intact skin [143]. The allergen is bound to a thin plastic membrane that is placed onto the skin under an occlusive patch, similar to the approach for atopy patch testing $[144,145]$. The allergen is taken up by Langerhans cells in the epidermis. These are immune-competent antigen-presenting cells that have
40 
the ability to initiate a regulatory $\mathrm{T}$-cell response and communicate with regional lymph nodes. Daily application of EPIT patches containing $250 \mu \mathrm{g}$ of peanut for 12 months in patients with peanut allergy has been shown to significantly raise the threshold dose for allergic reactions on food challenge [146, 147]. The desensitization effect is not as marked as that of OIT, but the rate of adverse effects is minimal and mainly limited to local skin irritation where the EPIT patch has been applied [143]. Guidelines for the clinical use of OIT versus EPIT in clinical practice still have to be defined.

\section{Conclusion}

Based on recent research, food allergy prevention and treatment have undergone significant improvements. Further research is needed to inform the most effective food allergy prevention strategies at the population level (Table 1). Effective prevention has the potential to reverse the rising prevalence trends for food allergies. In addition, the wider application of food allergen immunotherapy may provide better health outcomes and improved quality of life for families affected by food allergies.

\section{Disclosure Statement}

Dr. Ralf G. Heine is an employee of Nestlé Health Science, Switzerland. There are no other disclosures.

\section{References}

1 Sicherer SH, Sampson HA: Food allergy: Epidemiology, pathogenesis, diagnosis, and treatment. J Allergy Clin Immunol 2014;133: 291-307; quiz 308.

2 Jones SM, Burks AW: Food allergy. N Engl J Med 2017;377:2294-2295.

3 Renz H, Allen KJ, Sicherer SH, Sampson HA, Lack G, Beyer K, Oettgen HC: Food allergy. Nat Rev Dis Primers 2018;4:17098.

4 Koplin JJ, Mills EN, Allen KJ: Epidemiology of food allergy and food-induced anaphylaxis: is there really a Western world epidemic? Curr Opin Allergy Clin Immunol 2015;15: 409-416.

5 Dunlop JH, Keet CA: Epidemiology of food allergy. Immunol Allergy Clin North Am 2018;38:13-25.

6 Osborne NJ, Koplin JJ, Martin PE, Gurrin LC, Lowe AJ, Matheson MC, Ponsonby AL, Wake M, Tang ML, Dharmage SC, Allen KJ; HealthNuts Investigators: Prevalence of challengeproven IgE-mediated food allergy using population-based sampling and predetermined challenge criteria in infants. J Allergy Clin Immunol 2011;127:668-676.e1-e2.

7 Turner PJ, Campbell DE: Epidemiology of severe anaphylaxis: can we use populationbased data to understand anaphylaxis? Curr Opin Allergy Clin Immunol 2016;16:441450.

8 Ring J, Akdis C, Behrendt H, Lauener RP, Schappi G, Akdis M, et al: Davos declaration: allergy as a global problem. Allergy 2012;67: 141-143.

9 Du Toit G, Foong RM, Lack G: Prevention of food allergy - early dietary interventions. Allergol Int 2016;65:370-377.
10 Fiocchi A, Assa'ad A, Bahna S; Adverse Reactions to Foods Committee; American College of Allergy, Asthma and Immunology: Food allergy and the introduction of solid foods to infants: a consensus document. Adverse Reactions to Foods Committee, American College of Allergy, Asthma and Immunology. Ann Allergy Asthma Immunol 2006;97:1020.

11 Lack G, Fox D, Northstone K, Golding J, Avon Longitudinal Study of Parents and Children Study Team: Factors associated with the development of peanut allergy in childhood. N Engl J Med 2003;348:977-985.

12 Lack G, Golding J: Peanut and nut allergy. Reduced exposure might increase allergic sensitisation. BMJ 1996;313:300.

13 Burbank AJ, Sood P, Vickery BP, Wood RA: Oral immunotherapy for food allergy. Immunol Allergy Clin North Am 2016;36:55-69.

14 Aitoro R, Paparo L, Amoroso A, Di Costanzo M, Cosenza L, Granata V, Di Scala C, Nocerino R, Trinchese G, Montella M, Ercolini D, Berni Canani R: Gut microbiota as a target for preventive and therapeutic intervention against food allergy. Nutrients 2017;9:E672.

15 Berni Canani R, Di Costanzo M, Bedogni G, Amoroso A, Cosenza L, Di Scala C, Granata V, Nocerino R: Extensively hydrolyzed casein formula containing Lactobacillus rhamnosus GG reduces the occurrence of other allergic manifestations in children with cow's milk allergy: 3-year randomized controlled trial. J Allergy Clin Immunol 2017;139:19061913.e4.

16 West CE, Jenmalm MC, Prescott SL: The gut microbiota and its role in the development of allergic disease: a wider perspective. Clin Exp Allergy 2015;45:43-53.
17 Kramer MS: Breastfeeding and allergy: the evidence. Ann Nutr Metab 2011;59(suppl 1): 20-26.

18 Greer FR, Sicherer SH, Burks AW; American Academy of Pediatrics Committee on Nutrition; American Academy of Pediatrics Section on Allergy and Immunology: Effects of early nutritional interventions on the development of atopic disease in infants and children: the role of maternal dietary restriction, breastfeeding, timing of introduction of complementary foods, and hydrolyzed formulas. Pediatrics 2008;121:183-191.

19 Agostoni C, Decsi T, Fewtrell M, Goulet O, Kolacek S, Koletzko B, Michaelsen KF, Moreno L, Puntis J, Rigo J, Shamir R, Szajewska H, Turck D, van Goudoever J; ESPGHAN Committee on Nutrition: Complementary feeding: a commentary by the ESPGHAN Committee on Nutrition. J Pediatr Gastroenterol Nutr 2008;46:99-110.

20 Prescott SL, Tang ML; Australasian Society of Clinical Immunology and Allergy: The Australasian Society of Clinical Immunology and Allergy position statement: summary of allergy prevention in children. Med J Aust 2005; 182:464-467.

21 Kramer MS, Matush L, Vanilovich I, Platt R, Bogdanovich N, Sevkovskaya Z, Dzikovich I, Shishko G, Mazer B; Promotion of Breastfeeding Intervention Trial (PROBIT) Study Group: Effect of prolonged and exclusive breast feeding on risk of allergy and asthma: cluster randomised trial. BMJ 2007;335:815.

22 Turner PJ, Campbell DE: Implementing primary prevention for peanut allergy at a population level. JAMA 2017;317:1111-1112. 
23 Tey D, Allen KJ, Peters RL, Koplin JJ, Tang ML, Gurrin LC, Ponsonby AL, Lowe AJ, Wake M, Dharmage SC; HealthNuts study investigators: Population response to change in infant feeding guidelines for allergy prevention. J Allergy Clin Immunol 2014;133:476484.

24 Kleinman RE: American Academy of Pediatrics recommendations for complementary feeding. Pediatrics 2000;106:1274.

25 Fewtrell M, Bronsky J, Campoy C, Domellof M, Embleton N, Fidler Mis N, Hojsak I, Hulst $\mathrm{JM}$, Indrio F, Lapillonne A, Molgaard C: Complementary feeding: a position paper by the European Society for Paediatric Gastroenterology, Hepatology, and Nutrition (ESPGHAN) Committee on Nutrition. J Pediatr Gastroenterol Nutr 2017;64:119-132.

26 Thygarajan A, Burks AW: American Academy of Pediatrics recommendations on the effects of early nutritional interventions on the development of atopic disease. Curr Opin Pediatr 2008;20:698-702.

27 Sicherer SH, Allen K, Lack G, Taylor SL, Donovan SM, Oria M: Critical issues in food allergy: a national academies consensus report. Pediatrics 2017, Epub ahead of print.

28 Muraro A, Dubois AE, DunnGalvin A, Hourihane JO, de Jong NW, Meyer R, Panesar SS, Roberts G, Salvilla S, Sheikh A, Worth A Flokstra-de Blok BM; European Academy of Allergy and Clinical Immunology: EAACI Food Allergy and Anaphylaxis Guidelines. Food allergy health-related quality of life measures. Allergy 2014;69:845-853.

29 Isolauri E: Development of healthy gut microbiota early in life. J Paediatr Child Health 2012;48(suppl 3):1-6.

30 Fritz JH, Le Bourhis L, Magalhaes JG, Philpott DJ: Innate immune recognition at the epithelial barrier drives adaptive immunity: APCs take the back seat. Trends Immunol 2008;29: 41-49.

31 Saarinen UM, Kajosaari M: Breastfeeding as prophylaxis against atopic disease: prospective follow-up study until 17 years old. Lancet 1995;346:1065-1069.

32 Gdalevich M, Mimouni D, David M, Mimouni M: Breast-feeding and the onset of atopic dermatitis in childhood: a systematic review and meta-analysis of prospective studies. J Am Acad Dermatol 2001;45:520-527.

33 Snijders BE, Thijs C, Dagnelie PC, Stelma FF, Mommers M, Kummeling I, Penders J, van Ree R, van den Brandt PA: Breast-feeding duration and infant atopic manifestations, by maternal allergic status, in the first 2 years of life (KOALA study). J Pediatr 2007;151:347351.e1-e2.

34 Järvinen KM, Mäkinen-Kiljunen S, Suomalainen $\mathrm{H}$ : Cow's milk challenge through human milk evokes immune responses in infants with cow's milk allergy. J Pediatr 1999; $135: 506-512$
35 Pittschieler K: Cow's milk protein-induced colitis in the breast-fed infant. J Pediatr Gastroenterol Nutr 1990;10:548-549.

36 Hill DJ, Heine RG, Cameron DJ, Francis DE, Bines JE: The natural history of intolerance to soy and extensively hydrolyzed formula in infants with multiple food protein intolerance. J Pediatr 1999;135:118-121.

37 de Boissieu D, Matarazzo P, Rocchiccioli F, Dupont C: Multiple food allergy: a possible diagnosis in breastfed infants. Acta Paediatr 1997;86:1042-1046.

38 Mofidi S: Nutritional management of pediatric food hypersensitivity. Pediatrics 2003;111: 1645-1653.

39 Groetch M, Henry M, Feuling MB, Kim J: Guidance for the nutrition management of gastrointestinal allergy in pediatrics. J Allergy Clin Immunol Pract 2013;1:323-331.

40 Isolauri E, Sütas Y, Mäkinen-Kiljunen S, Oja SS, Isosomppi R, Turjanmaa K: Efficacy and safety of hydrolyzed cow milk and amino acid-derived formulas in infants with cow milk allergy. J Pediatr 1995;127:550-557.

41 Lucarelli S, Di Nardo G, Lastrucci G D'Alfonso Y, Marcheggiano A, Federici T, Frediani S, Frediani T, Cucchiara S: Allergic proctocolitis refractory to maternal hypoallergenic diet in exclusively breast-fed infants: a clinical observation. BMC Gastroenterol 2011;11:82.

42 Meyer R, Groetch M, Venter C: When should infants with cow's milk protein allergy use an amino acid formula? A practical guide. J Allergy Clin Immunol Pract 2018;6:383-399.

43 Kramer MS, Kakuma R: Maternal dietary antigen avoidance during pregnancy or lactation, or both, for preventing or treating atopic disease in the child. Evid Based Child Health 2014;9:447-483.

44 Muraro A, Dreborg S, Halken S, Host A, Niggemann B, Aalberse R, Arshad SH, Berg Av A, Carlsen K, Duschen K, Eigenmann P, Hill D, Jones C, Mellon M, Oldeus G, Oranje A, Pascual C, Prescott S, Sampson H, Svartengren $\mathrm{M}$, Vandenplas $\mathrm{Y}$, Wahn U, Warner JA, Warner JO, Wickman M, Zeiger RS: Dietary prevention of allergic diseases in infants and small children. Part I: Immunologic background and criteria for hypoallergenicity. Pediatr Allergy Immunol 2004;15:103-111.

45 Laubereau B, Brockow I, Zirngibl A, Koletzko S, Gruebl A, von Berg A, Filipiak-Pittroff B, Berdel D, Bauer CP, Reinhardt D, Heinrich J, Wichmann HE; GINI Study Group: Effect of breast-feeding on the development of atopic dermatitis during the first 3 years of life - results from the GINI-birth cohort study. J Pediatr 2004;144:602-607.
46 Fiocchi A, Burks W, Bahna SL, Bielory L, Boyle RJ, Cocco R, Dreborg S, Goodman R, Kuitunen M, Haahtela T, Heine RG, Lack G, Osborn DA, Sampson H, Tannock GW, Lee BW; WAO Special Committee on Food Allergy and Nutrition: Clinical Use of Probiotics in Pediatric Allergy (CUPPA): A World Allergy Organization Position Paper. World Allergy Organ J 2012;5:148-167.

47 Boehm G, Jelinek J, Stahl B, van Laere K, Knol J, Fanaro S, Moro G, Vigi V: Prebiotics in infant formulas. J Clin Gastroenterol 2004;38: S76-S79.

48 Fleischer DM, Sicherer S, Greenhawt $\mathrm{M}$, Campbell D, Chan E, Muraro A, et al: Consensus communication on early peanut introduction and prevention of peanut allergy in high-risk infants. Pediatr Dermatol 2016;33: 103-106.

49 Michel S, Busato F, Genuneit J, Pekkanen J, Dalphin JC, Riedler J, Mazaleyrat N, Weber J, Karvonen AM, Hirvonen MR, Braun-Fahrländer C, Lauener R, von Mutius E, Kabesch M, Tost J; PASTURE study group: Farm exposure and time trends in early childhood may influence DNA methylation in genes related to asthma and allergy. Allergy 2013;68: 355-364.

50 Allen KJ, Koplin JJ, Ponsonby AL, Gurrin LC, Wake M, Vuillermin P, Martin P, Matheson M, Lowe A, Robinson M, Tey D, Osborne NJ, Dang T, Tina Tan HT, Thiele L, Anderson D, Czech H, Sanjeevan J, Zurzolo G, Dwyer T, Tang ML, Hill D, Dharmage SC: Vitamin D insufficiency is associated with challengeproven food allergy in infants. J Allergy Clin Immunol 2013;131:1109-1116.e1-e6.

51 von Mutius E: Influences in allergy: epidemiology and the environment. J Allergy Clin Immunol 2004;113:373-379.

52 West CE, Dzidic M, Prescott SL, Jenmalm MC: Bugging allergy; role of pre-, pro- and synbiotics in allergy prevention. Allergol Int 2017;66:529-538.

53 West CE, Renz H, Jenmalm MC, Kozyrskyj AL, Allen KJ, Vuillermin P, Prescott SL; inFLAME Microbiome Interest Group: The gut microbiota and inflammatory noncommunicable diseases: associations and potentials for gut microbiota therapies. J Allergy Clin Immunol 2015;135:3-13.

54 Abrahamsson TR, Jakobsson HE, Andersson AF, Björkstén B, Engstrand L, Jenmalm MC: Low diversity of the gut microbiota in infants with atopic eczema. J Allergy Clin Immunol 2012;129:434-440.e1-e2.

55 Riedler J, Eder W, Oberfeld G, Schreuer M: Austrian children living on a farm have less hay fever, asthma and allergic sensitization. Clin Exp Allergy 2000;30:194-200.

56 Ege MJ: Intestinal microbial diversity in infancy and allergy risk at school age. J Allergy Clin Immunol 2011;128:653-654. 
57 Ege MJ, Mayer M, Normand AC, Genuneit J, Cookson WO, Braun-Fahrländer C, Heederik D, Piarroux R, von Mutius E; GABRIELA Transregio 22 Study Group: Exposure to environmental microorganisms and childhood asthma. N Engl J Med 2011;364: 701-709.

58 Ismail IH, Oppedisano F, Joseph SJ, Boyle RJ, Licciardi PV, Robins-Browne RM, Tang ML: Reduced gut microbial diversity in early life is associated with later development of eczema but not atopy in high-risk infants. Pediatr Allergy Immunol 2012;23:674-681.

59 Penders J, Thijs C, van den Brandt PA, Kummeling I, Snijders B, Stelma F, Adams H, van Ree R, Stobberingh EE: Gut microbiota composition and development of atopic manifestations in infancy: the KOALA Birth Cohort Study. Gut 2007;56:661-667.

60 Forsberg A, West CE, Prescott SL, Jenmalm MC: Pre- and probiotics for allergy prevention: time to revisit recommendations? Clin Exp Allergy 2016;46:1506-1521.

61 West CE: Probiotics for allergy prevention. Benef Microbes 2016;7:171-179.

62 Osborn DA, Sinn JK: Prebiotics in infants for prevention of allergic disease and food hypersensitivity. Cochrane Database Syst Rev 2007:CD006474.

63 Fiocchi A, Pawankar R, Cuello-Garcia C, Ahn K, Al-Hammadi S, Agarwal A, Beyer K, Burks W, Canonica GW, Ebisawa M, Gandhi S, Kamenwa R, Lee BW, Li H, Prescott S, Riva JJ, Rosenwasser L, Sampson H, Spigler M, Terracciano L, Vereda-Ortiz A, Waserman S, Yepes-Nunez JJ, Brozek JL, Schunemann HJ: World Allergy Organization-McMaster University Guidelines for Allergic Disease Prevention (GLAD-P): Probiotics. World Allergy Organ J 2015;8:4.

64 Cuello-Garcia CA, Fiocchi A, Pawankar R, Yepes-Nunez JJ, Morgano GP, Zhang Y, Ahn K, Al-Hammadi S, Agarwal A, Gandhi S, Beyer K, Burks W, Canonica GW, Ebisawa M, Kamenwa R, Lee BW, Li H, Prescott S, Riva JJ, Rosenwasser L, Sampson H, Spigler M, Terracciano L, Vereda A, Waserman S, Schünemann HJ, Brozek JL: World Allergy Organization-McMaster University Guidelines for Allergic Disease Prevention (GLAD-P): Prebiotics. World Allergy Organ J 2016;9:10.

65 Björksten B: The epidemiology of food allergy. Curr Opin Allergy Clin Immunol 2001; 225-227.

66 Rautava S, Collado MC, Salminen S, Isolauri E: Probiotics modulate host-microbe interaction in the placenta and fetal gut: a randomized, double-blind, placebo-controlled trial. Neonatology 2012;102:178-184.

67 Kalliomäki M, Salminen S, Arvilommi H, Kero P, Koskinen P, Isolauri E: Probiotics in primary prevention of atopic disease: a randomised placebo-controlled trial. Lancet 2001;357:1076-1079.
68 Abrahamsson TR, Jakobsson T, Böttcher MF, Fredrikson M, Jenmalm MC, Björkstén B, Oldaeus G: Probiotics in prevention of IgE-associated eczema: a double-blind, randomized, placebo-controlled trial. J Allergy Clin Immunol 2007;119:1174-1180.

69 Kukkonen K, Savilahti E, Haahtela T, Juntunen-Backman K, Korpela R, Poussa T, Tuure T, Kuitunen M: Probiotics and prebiotic galacto-oligosaccharides in the prevention of allergic diseases: a randomized, double-blind, placebo-controlled trial. J Allergy Clin Immunol 2007;119:192-198.

70 Taylor AL, Dunstan JA, Prescott SL: Probiotic supplementation for the first 6 months of life fails to reduce the risk of atopic dermatitis and increases the risk of allergen sensitization in high-risk children: a randomized controlled trial. J Allergy Clin Immunol 2007;119: 184-191.

71 Donovan SM, Wang M, Li M, Friedberg I, Schwartz SL, Chapkin RS: Host-microbe interactions in the neonatal intestine: role of human milk oligosaccharides. Adv Nutr 2012;3: 450S-455S.

72 Haarman M, Knol J: Quantitative real-time PCR analysis of fecal Lactobacillus species in infants receiving a prebiotic infant formula. Appl Environ Microbiol 2006;72:2359-2365.

73 Scholtens PA, Alles MS, Bindels JG, van der Linde EG, Tolboom JJ, Knol J: Bifidogenic effects of solid weaning foods with added prebiotic oligosaccharides: a randomised controlled clinical trial. J Pediatr Gastroenterol Nutr 2006;42:553-559.

74 Moro G, Arslanoglu S, Stahl B, Jelinek J, Wahn U, Boehm G: A mixture of prebiotic oligosaccharides reduces the incidence of atopic dermatitis during the first six months of age. Arch Dis Child 2006;91:814-819.

75 Grüber C, van Stuijvenberg M, Mosca F, Moro G, Chirico G, Braegger CP, Riedler J, Boehm G, Wahn U; MIPS 1 Working Group: Reduced occurrence of early atopic dermatitis because of immunoactive prebiotics among low-atopy-risk infants. J Allergy Clin Immunol 2010;126:791-797.

76 Bode L: The functional biology of human milk oligosaccharides. Early Hum Dev 2015;91: 619-622.

77 Thongaram T, Hoeflinger JL, Chow J, Miller MJ: Human milk oligosaccharide consumption by probiotic and human-associated Bifidobacteria and Lactobacilli. J Dairy Sci 2017; 100:7825-7833.

78 Puccio G, Alliet P, Cajozzo C, Janssens E, Corsello G, Sprenger N, Wernimont S, Egli D, Gosoniu L, Steenhout P: Effects of infant formula with human milk oligosaccharides on growth and morbidity: a randomized multicenter trial. J Pediatr Gastroenterol Nutr 2017;64:624-631.

79 Castillo-Courtade L, Han S, Lee S, Mian FM, Buck R, Forsythe P: Attenuation of food allergy symptoms following treatment with human milk oligosaccharides in a mouse model. Allergy 2015;70:1091-1102.
80 Pretorius R, Prescott SL, Palmer DJ: Taking a prebiotic approach to early immunomodulation for allergy prevention. Expert Rev Clin Immunol 2018;14:43-51.

81 Seppo AE, Autran CA, Bode L, Järvinen KM: Human milk oligosaccharides and development of cow's milk allergy in infants. J Allergy Clin Immunol 2017;139:708-711.e5.

82 Noval Rivas M, Burton OT, Wise P, Charbonnier LM, Georgiev P, Oettgen HC, Rachid R, Chatila TA: Regulatory $\mathrm{T}$ cell reprogramming toward a Th2-cell-like lineage impairs oral tolerance and promotes food allergy. Immunity 2015;42:512-523.

83 Deckers J, De Bosscher K, Lambrecht BN, Hammad H: Interplay between barrier epithelial cells and dendritic cells in allergic sensitization through the lung and the skin. Immunol Rev 2017;278:131-144.

84 Prescott SL, Smith P, Tang M, Palmer DJ, Sinn J, Huntley SJ, Cormack B, Heine RG, Gibson RA, Makrides M: The importance of early complementary feeding in the development of oral tolerance: concerns and controversies. Pediatr Allergy Immunol 2008;19: 375-380.

85 Koplin JJ, Osborne NJ, Wake M, Martin PE, Gurrin LC, Robinson MN, Tey D, Slaa M, Thiele L, Miles L, Anderson D, Tan T, Dang TD, Hill DJ, Lowe AJ, Matheson MC, Ponsonby AL, Tang ML, Dharmage SC, Allen KJ: Can early introduction of egg prevent egg allergy in infants? A population-based study. J Allergy Clin Immunol 2010;126:807-813.

86 Du Toit G, Roberts G, Sayre PH, Bahnson HT, Radulovic S, Santos AF, Brough HA, Phippard D, Basting M, Feeney M, Turcanu V, Sever ML, Gomez Lorenzo M, Plaut M, Lack G; LEAP Study Team: Randomized trial of peanut consumption in infants at risk for peanut allergy. N Engl J Med 2015;372:803-813.

87 Greenhawt M, Fleischer DM, Chan ES, Venter C, Stukus D, Gupta R, Spergel JM: LEAPing through the looking glass: secondary analysis of the effect of skin test size and age of introduction on peanut tolerance after early peanut introduction. Allergy 2017;72:12541260.

88 Perkin MR, Logan K, Marrs T, Radulovic S, Craven J, Flohr C, Lack G; EAT Study Team: Enquiring About Tolerance (EAT) study: feasibility of an early allergenic food introduction regimen. J Allergy Clin Immunol 2016; 137:1477-1486 e8.

89 von Berg A, Koletzko S, Grubl A, Filipiak-Pittroff B, Wichmann HE, Bauer CP, Reinhardt D, Berdel D; German Infant Nutritional Intervention Study Group: The effect of hydrolyzed cow's milk formula for allergy prevention in the first year of life: the German Infant Nutritional Intervention Study, a randomized double-blind trial. J Allergy Clin Immunol 2003;111:533-540. 
90 von Berg A, Filipiak-Pittroff B, Kramer U, Hoffmann B, Link E, Beckmann C, Hoffmann U, Reinhardt D, Grubl A, Heinrich J, Wichmann HE, Bauer CP, Koletzko S, Berdel D; GINIplus study group: Allergies in highrisk schoolchildren after early intervention with cow's milk protein hydrolysates: 10year results from the German Infant Nutritional Intervention (GINI) study. J Allergy Clin Immunol 2013;131:1565-1573.

91 Osborn DA, Sinn J: Formulas containing hydrolysed protein for prevention of allergy and food intolerance in infants. Cochrane Database Syst Rev 2006:CD003664.

92 Alexander DD, Cabana MD: Partially hydrolyzed $100 \%$ whey protein infant formula and reduced risk of atopic dermatitis: a meta-analysis. J Pediatr Gastroenterol Nutr 2010;50:422-430.

93 Szajewska H, Horvath A: Meta-analysis of the evidence for a partially hydrolyzed $100 \%$ whey formula for the prevention of allergic diseases. Curr Med Res Opin 2010;26:423437.

94 Lowe AJ, Hosking CS, Bennett CM, Allen KJ, Axelrad C, Carlin JB, Abramson MJ, Dharmage SC, Hill DJ: Effect of a partially hydrolyzed whey infant formula at weaning on risk of allergic disease in high-risk children: a randomized controlled trial. J Allergy Clin Immunol 2011;128:360-365.e4.

95 Lowe AJ, Dharmage SC, Allen KJ, Tang ML, Hill DJ: The role of partially hydrolyzed whey formula for the prevention of allergic disease: evidence and gaps. Expert Rev Clin Immunol 2013;9:31-41.

96 Boyle RJ, Ierodiakonou D, Khan T, Chivinge J, Robinson Z, Geoghegan N, Jarrold K, Afxentiou T, Reeves T, Cunha S, Trivella M, Garcia-Larsen V, Leonardi-Bee J: Hydrolysed formula and risk of allergic or autoimmune disease: systematic review and metaanalysis. BMJ 2016;352:1974.

97 Szajewska H, Horvath A: A partially hydrolyzed $100 \%$ whey formula and the risk of eczema and any allergy: an updated meta-analysis. World Allergy Organ J 2017;10:27.

98 Muraro A, Halken S, Arshad SH, Beyer K, Dubois AE, Du Toit G, Eigenmann PA, Grimshaw KE, Høst A, Lack G, O’Mahony L, Papadopoulos NG, Panesar S, Prescott S, Roberts G, de Silva D, Venter C, Verhasselt V, Akdis AC, Sheikh A; EAACI Food Allergy and Anaphylaxis Guidelines Group: EAACI food allergy and anaphylaxis guidelines. Primary prevention of food allergy. Allergy 2014;69:590-601.

99 Paxton GA, Teale GR, Nowson CA, Mason RS, McGrath JJ, Thompson MJ, Siafarikas A, Rodda CP, Munns CF: Vitamin D and health in pregnancy, infants, children and adolescents in Australia and New Zealand: a position statement. Med J Aust 2013;198:142-143.

$100 \mathrm{Wjst} \mathrm{M}$ : Is vitamin D supplementation responsible for the allergy pandemic? Curr Opin Allergy Clin Immunol 2012;12:257262.
101 Allen KJ, Koplin JJ, Ponsonby AL, Gurrin LC, Wake M, Vuillermin P, Martin P, Matheson M, Lowe A, Robinson M, Tey D, Osborne NJ, Dang T, Tan HT, Thiele L, Anderson D, Czech H, Sanjeevan J, Zurzolo G, Dwyer T, Tang ML, Hill D, Dharmage SC: Vitamin D insufficiency is associated with challenge-proven food allergy in infants. J Allergy Clin Immunol 2013;131:1109-1116.

102 Osborne NJ, Ukoumunne OC, Wake M, Allen KJ: Prevalence of eczema and food allergy is associated with latitude in Australia. J Allergy Clin Immunol 2012;129:865-867.

103 Wjst M: The vitamin D slant on allergy. Pediatr Allergy Immunol 2006;17:477-483.

104 Weisse K, Winkler S, Hirche F, Herberth G, Hinz D, Bauer M, Roder S, Rolle-Kampczyk U, von Bergen M, Olek S, Sack U, Richter T, Diez U, Borte M, Stangl GI, Lehmann I: Maternal and newborn vitamin $\mathrm{D}$ status and its impact on food allergy development in the German LINA cohort study. Allergy 2013; 68:220-228.

105 Allen KJ, Panjari M, Koplin JJ, Ponsonby AL, Vuillermin P, Gurrin LC, Greaves R, Carvalho N, Dalziel K, Tang ML, Lee KJ, Wake M, Curtis N, Dharmage SC: VITALITY trial: protocol for a randomised controlled trial to establish the role of postnatal vitamin $\mathrm{D}$ supplementation in infant immune health. BMJ Open 2015;5:e009377.

106 Prescott SL, Dunstan JA: Prenatal fatty acid status and immune development: the pathways and the evidence. Lipids 2007;42:801-810.

107 Dunstan JA, Mitoulas LR, Dixon G, Doherty DA, Hartmann PE, Simmer K, Prescott SL: The effects of fish oil supplementation in pregnancy on breast milk fatty acid composition over the course of lactation: a randomized controlled trial. Pediatr Res 2007;62: 689-694.

108 Krauss-Etschmann S, Hartl D, Rzehak P, Heinrich J, Shadid R, Del Carmen RamirezTortosa M, Campoy C, Pardillo S, Schendel DJ, Decsi T, Demmelmair H, Koletzko BV; Nutraceuticals for Healthier Life Study Group: Decreased cord blood IL-4, IL-13, and CCR4 and increased TGF-beta levels after fish oil supplementation of pregnant women. J Allergy Clin Immunol 2008;121: 464-470.e6.

109 Palmer DJ, Sullivan T, Gold MS, Prescott SL, Heddle R, Gibson RA, Makrides M: Effect of n-3 long chain polyunsaturated fatty acid supplementation in pregnancy on infants' allergies in first year of life: randomised controlled trial. BMJ 2012;344:e184

110 D’Vaz N, Meldrum SJ, Dunstan JA, Martino D, McCarthy S, Metcalfe J, Tulic MK, Mori TA, Prescott SL: Postnatal fish oil supplementation in high-risk infants to prevent allergy: randomized controlled trial. Pediatrics 2012;130:674-682.
111 Hill DJ, Murch SH, Rafferty K, Wallis P, Green CJ: The efficacy of amino acid-based formulas in relieving the symptoms of cow's milk allergy: a systematic review. Clin Exp Allergy 2007;37:808-822.

112 Fiocchi A, Brozek J, Schünemann $\mathrm{H}$, Bahna SL, von Berg A, Beyer K, Bozzola M, Bradsher J, Compalati E, Ebisawa M, Guzman MA, Li H, Heine RG, Keith P, Lack G, Landi M, Martelli A, Rancé F, Sampson H, Stein A, Terracciano L, Vieths S: World Allergy Organization (WAO) Diagnosis and Rationale for Action against Cow's Milk Allergy (DRACMA) Guidelines. World Allergy Organ J 2010;3:57-161.

113 Stensgaard A, Bindslev-Jensen C, Nielsen D, Munch M, DunnGalvin A: Quality of life in childhood, adolescence and adult food allergy: patient and parent perspectives. Clin Exp Allergy 2017;47:530-539.

114 Meyer R, Godwin H, Dziubak R, Panepinto JA, Foong RM, Bryon M, Lozinsky AC, Reeve K, Shah N: The impact on quality of life on families of children on an elimination diet for non-immunoglobulin E mediated gastrointestinal food allergies. World Allergy Organ J 2017;10:8.

115 Zurzolo GA, Mathai ML, Koplin JJ, Allen KJ: Hidden allergens in foods and implications for labelling and clinical care of food allergic patients. Curr Allergy Asthma Rep 2012;12: 292-296.

116 Turner PJ, Allen KJ, Mehr S, Campbell DE: Knowledge, practice, and views on precautionary allergen labeling for the management of patients with IgE-mediated food allergy - a survey of Australasian and UK health care professionals. J Allergy Clin Immunol Pract 2016;4:165-167.e14.

117 Begen FM, Barnett J, Payne R, Gowland MH, DunnGalvin A, Lucas JS: Eating out with a food allergy in the UK: Change in the eating out practices of consumers with food allergy following introduction of allergen information legislation. Clin Exp Allergy 2018;48: 317-324.

118 Palmer DJ, Makrides M: Diet of lactating women and allergic reactions in their infants. Curr Opin Clin Nutr Metab Care 2006;9:284-288.

119 Kramer MS, Kakuma R: Maternal dietary antigen avoidance during pregnancy or lactation, or both, for preventing or treating atopic disease in the child. Cochrane Database Syst Rev 2012;9:CD000133.

120 Meyer R, De Koker C, Dziubak R, Godwin $\mathrm{H}$, Dominguez-Ortega G, Chebar Lozinsky A, Skrapac AK, Gholmie Y, Reeve K, Shah N: The impact of the elimination diet on growth and nutrient intake in children with food protein induced gastrointestinal allergies. Clin Transl Allergy 2016;6:25. 
121 Koletzko S, Niggemann B, Arato A, Dias JA, Heuschkel R, Husby S, Mearin ML, Papadopoulou A, Ruemmele FM, Staiano A, Schäppi MG, Vandenplas Y; European Society of Pediatric Gastroenterology, Hepatology and Nutrition: Diagnostic approach and management of cow's-milk protein allergy in infants and children: ESPGHAN GI Committee practical guidelines. J Pediatr Gastroenterol Nutr 2012;55:221-229.

122 Lambers TT, Gloerich J, van Hoffen E, Alkema W, Hondmann DH, van Tol EA: Clustering analyses in peptidomics revealed that peptide profiles of infant formulae are descriptive. Food Sci Nutr 2015;3:81-90.

123 Chauveau A, Nguyen-Grosjean VM, Jacquenet S, Richard C, Mouton-Faivre C: Immediate hypersensitivity to extensively hydrolyzed formulas: an important reminder. Pediatr Allergy Immunol 2016;27:541-543.

124 Muraro A, Høst A: Controversies on special products for managing cow's milk protein allergy in infants: Saftey and sutability. EMJ Allergy Immunol 2017;2:46-51.

125 Heine RG, AlRefaee F, Bachina P, De Leon JC, Geng L, Gong S, Madrazo JA, Ngamphaiboon J, Ong C, Rogacion JM: Lactose intolerance and gastrointestinal cow's milk allergy in infants and children - common misconceptions revisited. World Allergy Organ J 2017;10:41.

126 Francavilla R, Calasso M, Calace L, Siragusa S, Ndagijimana M, Vernocchi P, Brunetti L, Mancino G, Tedeschi G, Guerzoni E, Indrio F, Laghi L, Miniello VL, Gobbetti M, De Angelis M: Effect of lactose on gut microbiota and metabolome of infants with cow's milk allergy. Pediatr Allergy Immunol 2012;23:420-427.

127 American Academy of Pediatrics, Committee on Nutrition: Hypoallergenic infant formulas. Pediatrics 2000;106:346-349.

128 Nowak-Wegrzyn A, Chatchatee P: Mechanisms of tolerance induction. Ann Nutr Metab 2017;70(suppl 2):7-24.

129 Berni Canani R, Nocerino R, Terrin G, Coruzzo A, Cosenza L, Leone L, Troncone R: Effect of Lactobacillus GG on tolerance acquisition in infants with cow's milk allergy: a randomized trial. J Allergy Clin Immunol 2012;129:580-582.e1-e5.

130 Berni Canani R, Sangwan N, Stefka AT, Nocerino R, Paparo L, Aitoro R, Calignano A, Khan AA, Gilbert JA, Nagler CR: Lactobacillus rhamnosus GG-supplemented formula expands butyrate-producing bacterial strains in food allergic infants. ISME J 2016; 10:742-750.
131 de Boissieu D, Dupont C: Allergy to extensively hydrolyzed cow's milk proteins in infants: safety and duration of amino acidbased formula. J Pediatr 2002;141:271-273.

132 Liacouras CA, Furuta GT, Hirano I, Atkins D, Attwood SE, Bonis PA, Burks AW, Chehade M, Collins MH, Dellon ES, Dohil R, Falk GW, Gonsalves N, Gupta SK, Katzka DA, Lucendo AJ, Markowitz JE, Noel RJ, Odze RD, Putnam PE, Richter JE, Romero Y, Ruchelli E, Sampson HA, Schoepfer A, Shaheen NJ, Sicherer SH, Spechler S, Spergel JM, Straumann A, Wershil BK, Rothenberg ME, Aceves SS: Eosinophilic esophagitis: updated consensus recommendations for children and adults. J Allergy Clin Immunol 2011;128:3-20 e6; quiz 21-22.

133 Candy DCA, Van Ampting MTJ, Oude Nijhuis MM, Wopereis H, Butt AM, Peroni DG, Vandenplas Y, Fox AT, Shah N, West CE, Garssen J, Harthoorn LF, Knol J, Michaelis LJ: A synbiotic-containing aminoacid-based formula improves gut microbiota in non-IgE-mediated allergic infants. Pediatr Res 2017, Epub ahead of print.

134 Tzifi F, Grammeniatis V, Papadopoulos M: Soy- and rice-based formula and infant allergic to cow's milk. Endocr Metab Immune Disord Drug Targets 2014;14:38-46.

135 Fiocchi A, Restani P, Bernardini R, Lucarelli S, Lombardi G, Magazzu G, Marseglia GL, Pittschieler K, Tripodi S, Troncone R, Ranzini C: A hydrolysed rice-based formula is tolerated by children with cow's milk allergy: a multi-centre study. Clin Exp Allergy 2006; 36:311-316

136 Vandenplas Y, De Greef E, Hauser B; Paradice Study Group: Safety and tolerance of a new extensively hydrolyzed rice proteinbased formula in the management of infants with cow's milk protein allergy. Eur J Pediatr 2014;173:1209-1216.

137 Vitoria I: The nutritional limitations of plant-based beverages in infancy and childhood. Nutr Hosp 2017;34:1205-1214.

138 Järvinen KM, Chatchatee P: Mammalian milk allergy: clinical suspicion, cross-reactivities and diagnosis. Curr Opin Allergy Clin Immunol 2009;9:251-258.

139 Pessler F, Nejat M: Anaphylactic reaction to goat's milk in a cow's milk-allergic infant. Pediatr Allergy Immunol 2004;15:183-185.

140 Schofield AT: A case of egg poisoning. Lancet 1908;1:716.
141 Bird JA, Spergel JM, Jones SM, Rachid R, Assa'ad AH, Wang J, Leonard SA, Laubach SS, Kim EH, Vickery BP, Davis BP, Heimall J, Cianferoni A, MacGinnitie AJ, Crestani E, Burks AW; ARC001 Study Group: Efficacy and safety of AR101 in oral immunotherapy for peanut allergy: results of ARC001, a randomized, double-blind, placebo-controlled phase 2 clinical trial. J Allergy Clin Immunol Pract 2018;6:476-485.e3.

142 MacGinnitie AJ, Rachid R, Gragg H, Little SV, Lakin P, Cianferoni A, Heimall J, Makhija M, Robison R, Chinthrajah RS, Lee J, Lebovidge J, Dominguez T, Rooney C, Lewis MO, Koss J, Burke-Roberts E, Chin K, Logvinenko T, Pongracic JA, Umetsu DT, Spergel J, Nadeau KC, Schneider LC: Omalizumab facilitates rapid oral desensitization for peanut allergy. J Allergy Clin Immunol 2017;139:873-881 e8

143 Wang J, Sampson HA: Safety and efficacy of epicutaneous immunotherapy for food allergy. Pediatr Allergy Immunol 2018, Epub ahead of print.

144 Kalach N, Soulaines P, de Boissieu D, Dupont C: A pilot study of the usefulness and safety of a ready-to-use atopy patch test (Diallertest) versus a comparator (Finn Chamber) during cow's milk allergy in children. J Allergy Clin Immunol 2005; 116:1321-1326.

145 Benhamou PH, Kalach N, Soulaines P, Donne N, Dupont C: Ready-to-use house dust mites atopy patch test (HDM-Diallertest), a new screening tool for detection of house dust mites allergy in children. Eur Ann Allergy Clin Immunol 2009;41:146-151.

146 Sampson HA, Shreffler WG, Yang WH, Sussman GL, Brown-Whitehorn TF, Nadeau KC, Cheema AS, Leonard SA, Pongracic JA, Sauvage-Delebarre C, Assa'ad AH, de Blay F, Bird JA, Tilles SA, Boralevi F, Bourrier T, Hebert J, Green TD, Gerth van Wijk R, Knulst AC, Kanny G, Schneider LC, Kowalski ML, Dupont C: Effect of varying doses of epicutaneous immunotherapy vs placebo on reaction to peanut protein exposure among patients with peanut sensitivity: a randomized clinical trial. JAMA 2017;318:17981809.

147 Jones SM, Sicherer SH, Burks AW, Leung DY, Lindblad RW, Dawson P, Henning AK, Berin MC, Chiang D, Vickery BP, Pesek RD, Cho CB, Davidson WF, Plaut M, Sampson HA, Wood RA; Consortium of Food Allergy Research: Epicutaneous immunotherapy for the treatment of peanut allergy in children and young adults. J Allergy Clin Immunol 2017;139:1242-1252.e9. 